\title{
Biodiversity, Ecosystem and Commodities in Amazonia
}

\author{
Peter Mann de Toledo ${ }^{1}$, Ima Célia Guimarães Vieira² ${ }^{2}$ Gilberto Câmara ${ }^{1}$, \\ Roberto Araújo', Andrea Coelho ${ }^{3}$ and Sergio Gomes ${ }^{3}$ \\ ${ }^{1}$ Instituto Nacional de Pesquisas Espaciais \\ ${ }^{2}$ Museu Paraense Emilio Goeldi \\ ${ }^{3}$ Instituto de Desenvolvimento Econômico, Social e Ambiental do Pará \\ Brazil
}

\section{Introduction}

The Amazonian Region has undergone constant pressure from human activities in the past 100 years, with dramatic changes in the landscapes caused by significant impacts on a great number of rainforest biotic communities. Historical data show that the last pulse of expansion of the forest, which initiated 4-5,000 years ago (Burnham \& Johnson, 2004; Bush \& Silman, 2007), has been permanently halted due to intensification of land use and occupation along the southern ecological contact zone between the forest and savanna ecosystems. Such a pristine environment, in similar scale and richness as witnessed by the first Europeans who arrived in South America and wrestled the land from the Native South Americans, can no longer be preserved or even restored to its original state. Almost twenty percent of the primeval Amazon tropical forest has been altered or destroyed in Brazil, the country that encompasses most of this diverse biome.

An important portion of this original information is now preserved in maps, natural history and anthropology books and scientific collections (Moran \& Ostrom, 2009). Such documentation showing different pathways from these past 500 years is crucial to understand and learn from experiences of success and failure. Resiliency, adaptation and modification of a tropical environment rich in biodiversity have shaped a dynamic biome that shifted in magnitude and intensity in the past decades due to human activity (Joels \& Camara, 2001; Buckeridge, 2008). Understanding these successive events is one of the most important challenges facing the modern scientific community. Accurate information on science and technology can potentially improve the future management of a complex tropical environment.

The current trend of environmental awareness as reflected in the conservation, ecological services, global change and sustainable activities at odds with economic growth and tensions caused by social injustice in tropical regions have placed Amazonia under a worldwide spotlight in terms of collective consciousness for nature preservation. To reduce human impact and simultaneously preserve indigenous and other traditional cultures have been top priorities in the agendas of most Non Governmental Organizations. The level of scientific publications on different aspects of biological diversity in Brazilian Amazonia has been constantly improving. Similarly, public and private institutions are experiencing new 
and more thorough forms of partnership, with mutually complementary agendas, joining forces toward common goals in multidisciplinary approaches. Such actions and institutional strategies are closing the knowledge gap on the measuring of the impact of deforestation on species ecology and habitat losses, as it has been perceived that natural landscapes are being destroyed much faster than one could possibly understand the functioning of such ecosystems and organisms (Stuart et. al. 2010).

With population growth at current rates, more land for agriculture and energy supply will be demanded. In this context, a new trend of pressure wave on the Amazonian forest has initiated. The high potential for hydroelectric power and the availability of extensive areas for food and biofuel production are additional threats to conservation efforts. A globalized world and the current Amazonian economic strength exerts increasing demands for productive terrains, increasing the tension on deforestation and land use.

In this chapter we will address the dynamics of human occupation of Amazon biome, present the problems and perspectives of the main commodities in Para state and discuss the mechanism of Reducing Emission from Forest Deforestation and Degradation (REDD) and the challenges for solving the infrastructure/biological conservation duality in Amazonia.

\section{The Amazonian biome and the patterns of human occupation}

Throughout the new Anthropocene Era, the ever-diminishing pristine habitats, arranged into isolated sets of natural landscapes around the globe, are changing at a speedy rate due to an unplanned pressure on natural resources in the form of aggressive, non-sustainable actions of land use and conversion into croplands. The Amazonian Region, together with the African Continent, is regarded as one of the few remaining lands appropriate for agricultural expansion in the tropics. An increase in human population, the expansion of most Third World economies taking whole populations out of poverty levels, and technological improvement of food production will maintain such an ongoing pressure trend. The awareness of such a menace to natural habitats is instigating the scientific community to engage in transdisciplinary programs in order to ensure developmental actions that are in conformity with the sustainable use of natural resources.

The Amazonian Region holds the largest tropical forest in the planet, with a very high number of biological species and increasing numbers in all biodiversity categories. Such diversity, in scale and complexity, receives worldwide attention vis-à-vis conservation efforts and scientific interest. The total area of the Amazon basin is of nearly 6.7 million square kilometers, including parts of Bolivia, Brazil, Colombia, Ecuador, French Guiana, Peru, Surinam and Venezuela. Amazonia is dominated by dense humid tropical forests, but also contains exclusive habitats such as lowland forests, seasonally flooded areas ('várzeas' and 'igapós'), open areas, marshes, bamboo-dominated vegetations, mountain forests and palm forests. The entire region encompasses an area $50 \%$ as larger as the 27 European countries. Not only Amazonia houses half of the preserved tropical forests of the world, it also includes the latter's largest freshwater basin. The Amazon River, the main river system in this region, discharges into the Atlantic Ocean a water volume equivalent to $15 \%$ of the total freshwater flowing into the oceans worldwide.

The natural history of Amazonia has been shaped and controlled by alternating dynamic phases with more stable environmental conditions, remodeling its landscapes since the Miocene age. Despite an overall comparatively less intensive change in climatic regimes if 
compared to other regions of the world, especially during more recent glacial periods with drier climates, those differences were subtle enough to induce new local and regional conditions that may have been an important driver in modifying terrestrial biotic communities through time. Pulses of expansion and retraction of forests mixed with savanna-like habitats have been extensively recorded in the region throughout its geological history, as were alterations in river patterns and strong tectonic activity. Altogether, such ecological conditions and evolutionary pressure played an important role in forming the present pattern of spatial species distribution and endemism, resulting in a rich biota unevenly distributed over an extensive geographical area. Nevertheless, forests appear to have been the dominant landscape during most of the Recent period, especially in the last 7 thousand years. Consequently, the Amazonian biota comprises both ancient and recent species. There have been eight areas of endemism identified by means of the distribution patterns of avian communities and some groups of terrestrial plants, to wit: Belém, Napo, Guiana,Tapajós, Imeri, Inambari, Xingu and Rondônia (Silva et al., 2005).

Scientists have estimated that, despite the ongoing extinction crises, there are between 111 million and 3.6 billion species living in the planet. But only 1.7 million of those have been known and described by science. According to Mittermeier et al., (2005), there are 17 megadiverse countries, harboring disproportionally large fauna e flora in their territories, and Brazil is singled out as the largest of them all. Considering species already described and the potential numbers of those groups yet to be known, Brazil may account for $13 \%$ of the world's biota -- some 1.8 million species. Despite the large number of lifeforms described for the country - 13,000 species of fungi, 60,000 plant species, 136,000 animal species Brazilian biodiversity is still in need to be properly accounted for. In Amazonia, 40,000 plant species are known at the present, 75\% of them endemic. And at least 430 mammals, 1,300 birds, 400 amphibians and 3,000 fish species are known by taxonomic names (Instituto de Pesquisa Econômica Aplicada [IPEA], 2011). Ongoing research using newly-developed techniques of DNA sequencing may even increase these numbers by distinguishing between cryptic species, and many biological inventories are currently under way. On the other hand, according to the International Union for the Conservation of Nature [IUCN], the planet is undergoing a human-induced wave of extinction, threatening a significant number of animal and plant species.

In the past hundred years, land use in Amazonia has changed with respect to six major activities: mineral and forest exploitation, extensive rangeland for cattle, infrastructure projects for hydroelectric power plants, roads, colonization projects and, more recently, production of agricultural commodities (Araújo \& Lená, 2010).

Grounded on a developmentalist model, the Federal Government has induced a process of opening the frontier land that is distinct from prior similar processes, and characterized by an extensive and predatory use of natural resources, as represented in Table 1.

The Modern phase (1960-1980) is characterized by the dominance of a developmentalist ideology, implemented by an authoritarian State that did not hesitated in using bureaucratic strategies in order to regulate illegal practices of land tenure expropriation, in favor of a few large economic groups and companies.

Currently, there seems to be a trend of convergence among several of the productive and developmental sectors, both public and private, as well as some segments of the social and environmental fields, in the need to transform environmental assets into goods, resulting in a new panacea aiming at an ideally "developed" Amazonia (Araújo \& Lená, 2010). This rationale would be centered on the carbon trade of the biomass held by the forests, and, at a 


\begin{tabular}{|c|c|c|c|c|c|}
\hline $\begin{array}{l}\text { DEVELOPMENT } \\
\text { PHASES }\end{array}$ & DEMOGRAPHY & ECONOMY & $\begin{array}{l}\text { MODES OF SOCIAL } \\
\text { AND POLITICAL } \\
\text { PARTICIPATION }\end{array}$ & $\begin{array}{l}\text { ROLE OF } \\
\text { THE STATE }\end{array}$ & $\begin{array}{l}\text { NATURAL } \\
\text { ESOURCES }\end{array}$ \\
\hline $\begin{array}{l}\text { 1) } \\
\text { Colonial Model }\end{array}$ & $\begin{array}{l}\text { Genocide, Western } \\
\text { acculturation of } \\
\text { indigenous } \\
\text { populations, import } \\
\text { of exotic } \\
\text { populations }\end{array}$ & $\begin{array}{l}\text { Exploitation of } \\
\text { nature goods, } \\
\text { first } \\
\text { commercial } \\
\text { plantations } \\
\text { (for example, } \\
\text { cocoa trees) }\end{array}$ & $\begin{array}{l}\text { Slavery, forced labor, } \\
\text { working in religious } \\
\text { missions and military } \\
\text { recruitment }\end{array}$ & $\begin{array}{l}\text { Military } \\
\text { conquest and } \\
\text { confirmation } \\
\text { of territorial } \\
\text { dominance }\end{array}$ & $\begin{array}{l}\text { No restriction } \\
\text { in regional } \\
\text { ecosystem } \\
\text { exploitation }\end{array}$ \\
\hline $\begin{array}{l}\text { 2) } \\
\text { Debt peonage system }\end{array}$ & $\begin{array}{l}\text { Demographic } \\
\text { hecatomb (19th } \\
\text { Century) and } \\
\text { considerable extra- } \\
\text { regional } \\
\text { demographic } \\
\text { immigration }\end{array}$ & $\begin{array}{l}\text { Hegemony of } \\
\text { rubber } \\
\text { economy, } \\
\text { private } \\
\text { activities, } \\
\text { barter system }\end{array}$ & $\begin{array}{l}\text { Immobilization of work } \\
\text { force, exclusion from } \\
\text { the market and no } \\
\text { political engagement }\end{array}$ & $\begin{array}{l}\text { Weak State } \\
\text { intervention }\end{array}$ & $\begin{array}{l}\text { Unrestricted } \\
\text { and broad } \\
\text { exploitation of } \\
\text { regional } \\
\text { ecosystem } \\
\text { without } \\
\text { restoration of } \\
\text { Forest cover }\end{array}$ \\
\hline $\begin{array}{l}\text { 3) } \\
\text { Developmentalism }\end{array}$ & $\begin{array}{l}\text { Highly considerable } \\
\text { extra-regional } \\
\text { immigration, public } \\
\text { and private } \\
\text { settlements }\end{array}$ & $\begin{array}{l}\text { Governmental } \\
\text { investment in } \\
\text { infrastructure } \\
\text { and subsidies } \\
\text { to large } \\
\text { enterprises } \\
\text { from the } \\
\text { private sector. } \\
\text { Beginning of } \\
\text { wage } \\
\text { remuneration }\end{array}$ & $\begin{array}{l}\text { Authoritarian inclusion } \\
\text { in developmental } \\
\text { projects, exclusion of } \\
\text { local populations }\end{array}$ & $\begin{array}{l}\text { Authoritarian } \\
\text { State }\end{array}$ & $\begin{array}{l}\text { Massive } \\
\text { destruction of } \\
\text { the natural } \\
\text { capital and } \\
\text { substitution by } \\
\text { exotic } \\
\text { cultivations }\end{array}$ \\
\hline $\begin{array}{l}\text { 4) } \\
\text { Socio-environmental } \\
\text { model }\end{array}$ & $\begin{array}{l}\text { Intra-regional } \\
\text { demographic } \\
\text { recomposition, } \\
\text { spatial } \\
\text { differentiation }\end{array}$ & $\begin{array}{l}\text { Diversification } \\
\text { of investment } \\
\text { sources and } \\
\text { descentralizati } \\
\text { on of projects } \\
\text { and policies }\end{array}$ & $\begin{array}{l}\text { Collaborative and } \\
\text { participatory model }\end{array}$ & $\begin{array}{l}\text { Regulatory } \\
\text { State/Third } \\
\text { sector } \\
\text { (networks, } \\
\text { associativism, } \\
\text { participation } \\
\text { of the private } \\
\text { sector }\end{array}$ & $\begin{array}{l}\text { Giving value } \\
\text { for } \\
\text { biodiversity } \\
\text { and creating } \\
\text { sustainable } \\
\text { agricultural } \\
\text { systems }\end{array}$ \\
\hline $\begin{array}{l}\text { 5) } \\
\text { Commoditization of } \\
\text { environmental assets }\end{array}$ & $\begin{array}{l}\text { Intra-regional } \\
\text { demographic } \\
\text { recomposition, } \\
\text { spatial } \\
\text { differentiation }\end{array}$ & $\begin{array}{l}\text { Land tenure } \\
\text { market, } \\
\text { agribusiness, } \\
\text { financing of } \\
\text { private } \\
\text { initiatives }\end{array}$ & $\begin{array}{l}\text { Model of } \\
\text { administration of public } \\
\text { forest for timber } \\
\text { exploitation, legal } \\
\text { environmental clauses }\end{array}$ & \begin{tabular}{|l} 
Alliance of \\
State and \\
market \\
towards \\
environmental \\
protection
\end{tabular} & \begin{tabular}{|l|} 
Monetary \\
valuation of \\
environmental \\
services / \\
REDD
\end{tabular} \\
\hline
\end{tabular}

Table 1. Phases of development in the Amazonian Region (modified from Araújo \& Lena, 2010). 
more general level, on the logic of the ecological services in a worldwide global change situation (Diaz et al., 2009). According to that reasoning, if one establishes market values to ecosystems or parts of them, it would lead to more effective environmental protection, by bringing changes in land use patterns and/or by financing rural developments of small land owners or traditional communities - ultimately giving value to and conserving natural habitats. Such an hegemonic view of the international environmentalist community is having strong repercussions in Brazil, despite criticism from scientists and economists.

The different phases represented in Table 1 should not be seen as successive events, but partially overlapping, mutually interacting and even being recycled in different times and places in distinct portions of Amazonia. In this matter, it is important to adopt a critical view not only with respect to development and its many expressions (infrastructure, public financing programs for the expansion of cattle ranches and extensive soybean plantations, etc.), but also in regards to the actual logic of the social-environmental reasoning of the ecological market.

\section{Forest conversion and degradation in Amazonia and its insertion in the global context}

Global rates of deforestation have accelerated in the past decades, as shown recently by an international survey on the status of forest cover in the world. FAO reports that an average of $13 \times 10^{6}$ hectares of forest was converted annually in the last decade. In the tropics, a massive conversion of closed forests and arboreal savannas into rangeland has been the main operative causes of pressure on exclusive forest-dwelling species (Dirzo \& Raven, 2003). In fact, the great majority of threats to species classified as vulnerable or endangered, according to the IUCN 'red lists', are related to the conversion of natural habitats by agricultural projects, mainly in large tropical countries of emergent economies, such as Brazil (Green et al., 2005).

With $35 \%$ of the world's primary forest cover, Brazil has a key role in the conservation of forest organisms, as well as in maintaining the ecological services produced by such ecosystems (Stuart et al., 2010). The great majority of these services are not accounted for by conventional metrics of market economies, their importance being underestimated by urban consumers. Due to this, Brazil, as a large forest owner, also presents high rates of total forest cover, even if compared to other frontiers elsewhere in the globe. For instance, an aggregated deforestation average rate in Brazil in the past two decades (1990-2010: 2.8 X $10^{6}$ hectare/year) is well over the average rate registered in this same period in Indonesia, the country with the second greatest tropical forest. Most of the forest conversion and degradation in Amazonia were concentrated in regions with fertile soils and easy access to seasonally dry forest areas (Laurance et al 2002, Peres et al 2010), locally known as the Arc of Deforestation (Figure 1).

In a similar pace with the expansion of the largest areas of croplands for agribusiness, the second cycle of cattle production in Brazil induced the transformation of $80 \%$ of deforested areas into pasture, an area effectively occupied today by extensive ranches (Smeraldi \& May, 2008). In Amazonia alone, this area corresponds to an expansion of 57 million hectares of pastures to accommodate 80 million heads of cattle (Instituto Brasileiro de Geografia e Estatística [IBGE], 2006). Most of this beef production is to meet domestic and international demands, in a context of constant rising prices of agricultural commodities. Agribusiness has been very successful - due to the expansion of the production area by means of 
converting natural habitats in illegally owned public lands - and claims to provide for worldwide needs for food. Economic growth in Asia has dramatically changed the demand for agricultural products from Latin America: exporting biomass goods for China alone have increased nine-fold in the past decade (from US\$ 4.6 billion in 2000 to US\$ 41.,3 billion in 2009). Soybean exports from Brazil to China also increased between 1995 and 2009, much at the expense of the destruction of $528,000 \mathrm{~km}^{2}$ of Amazonian primary forests and savannas (Gallagher \& Porzecanski, 2010).

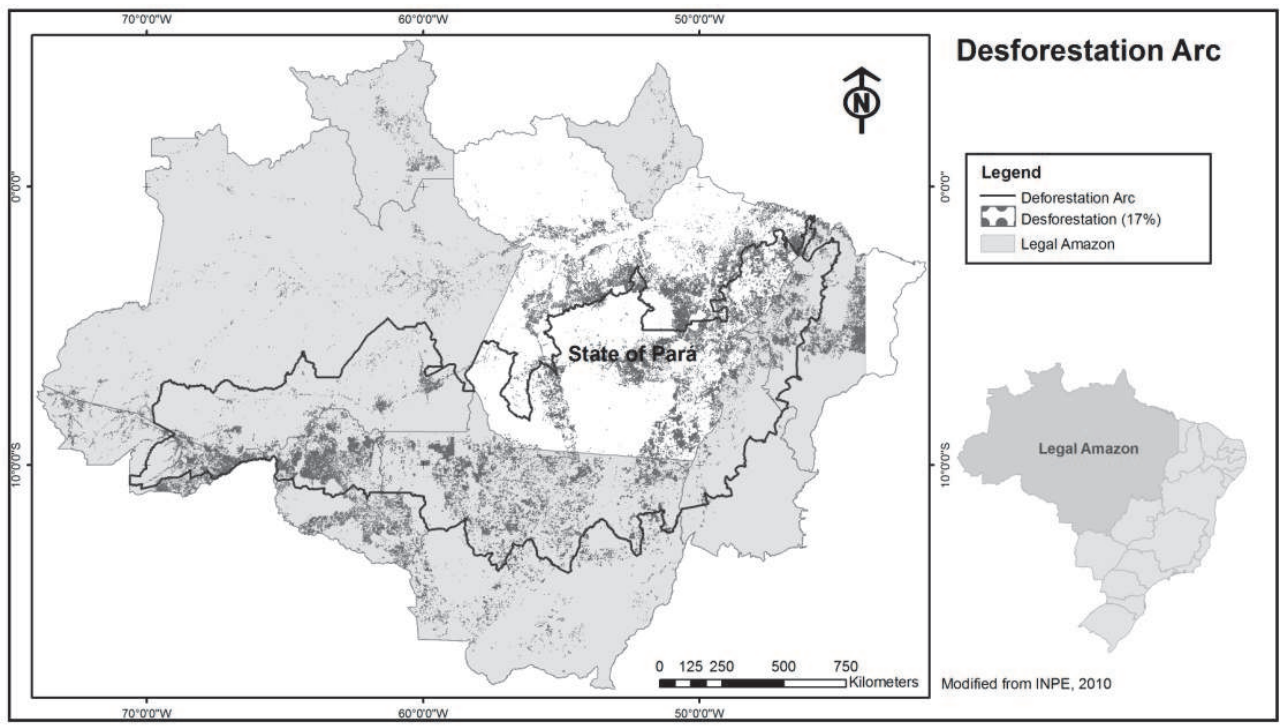

Source: PRODES/Instituto Nacional de Pesquisas Espaciais [INPE], 2010.

Fig. 1. Map of Amazonian deforestation.

Another threat to the impact of natural landscapes and ecosystems in the tropics is the ongoing expansion of the cultivation of plant species with potential for biofuel production Scharlemann \& Laurance (2008). Presently Brazil is considered a leader in the production of environmentally clean fuels, such as ethanol, due to the large and country-wide industrial production framework of sugarcane derivatives, with considerable help from fiscal incentives and other subsidies for rural production. Almost $95 \%$ of the total area for biofuels in South America is planted in Brazilian territory. Since 2004, sugarcane plantation area has expanded 50\%, and expected to double with new areas by 2018 (Sparovek, 2009). More recently, Brazil implemented a National Biodiesel Plan, and in Amazonia, the cultivation of oil palm has quickly grown. A drastic increase in palm trees cultivation is expected for the region.

The accelerated deforestation rate observed in the past 30 years has led to record high levels of landscape degradation and natural habitat destruction (Pereira et al., 2010). However, scientists have not yet been yet been able to fully correlate local loss of biodiversity with land conversion processes, and further elaborate regional comparisons, since different land use occupation patterns show distinct impacts on local ecological processes (Peres et al 2006). 
Figure 2 shows that the different components of a human-induced landscape in Eastern Amazonia, established according to its floristic diversity, should maintain a collectivity of species characteristic of the total area they occupy. For instance, the younger secondary forests may contribute with a smaller percentage to the total diversity level, due to its relatively smaller area of distribution. The preserved primary forests, despite their smaller area in the landscape, contribute at a considerably higher rate to the total floristic diversity, due to its higher specie density/area relationship.

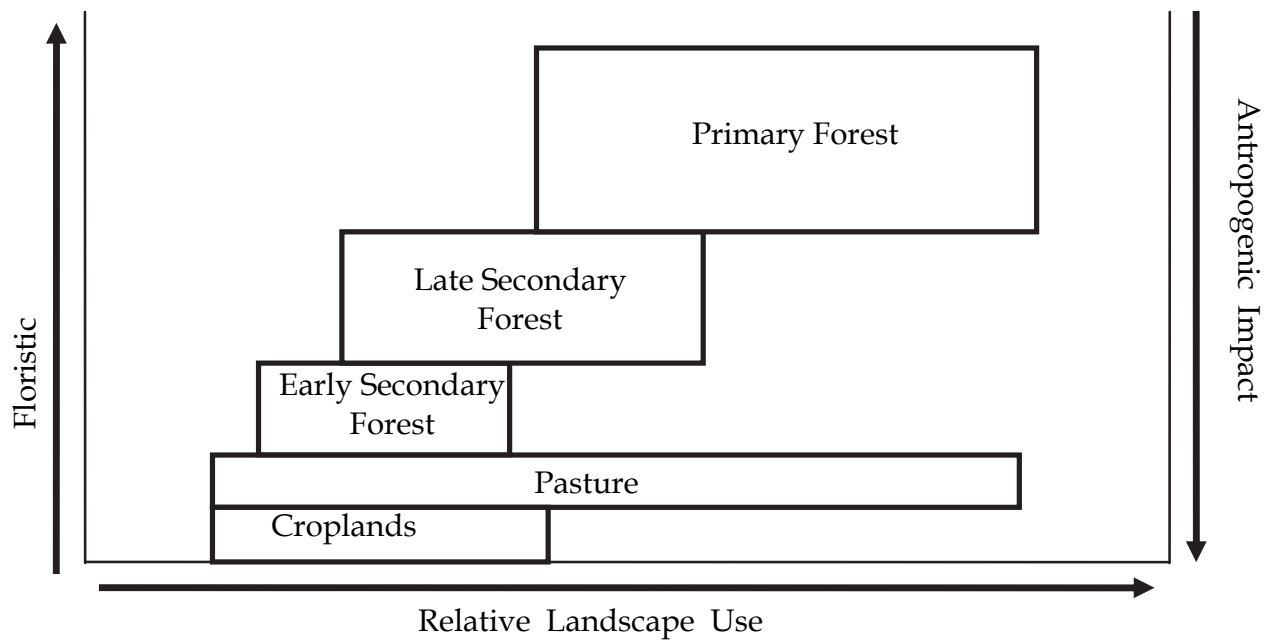

Fig. 2. Elements of human-made landscape in Eastern Amazonia as a function of the floristic diversity and relative landscape use (after Dirzo et al. 2009)

In the face of the dramatic rates of forest conversion in areas used for agricultural activities, (Vieira et al., 2008) it is important to maintain the heterogeneity of the landscape, including well-preserved areas of both primary and secondary forests. However, there is no scientific agreement on the ideal level of floristic biodiversity of each category to adequately maintain the ecological services so as to congregate production and conservation actions in a specific territory. Moreover, additional knowledge on biogeochemical interactions is needed, as is also necessary to maintain genetic diversity and other ecological processes for the equilibrium of the system (Mooney et al., 2009).

\section{Commodities in the Amazonian region: the State of Pará as a case study}

Brazil occupies a prominent place in the production of commodities crucial to the international markets, such as soybean, beef, corn, coffee beans and others (Martinelli et al., 2010). In this view, the Amazonian Region plays an important role in its potential as a frontier in expansion for the agribusiness sector. Due to recent debates related to environmental issues and mitigation actions to reduce global changes problems, Brazil has been undergoing strong international pressure to adopt procedures to bring social justice and even economic growth without further destruction of forested areas.

Due to its geographical characteristics and accessibility by roads, the State of Pará has always been a port of entry for expanding agricultural activities, one of the main causes of 
deforestation, particularly in the area known as Arc of Deforestation. Levels of forest cleaning have reached a total of $245,035 \mathrm{~km}^{2}$ in 2009 , equivalent to $19 \%$ of the State territory and $33 \%$ of the total deforested area in Brazil in that year.

The main productive activities in the state are cattle, timber exploitation, grain plantation and, more recently, cultivation of oil palm. This last culture calls the attention due to the rapid land tenure and demographic pattern changes that follow such an economic activity (Figure 3).

Cattle ranching is singled out as the main cause for deforestation in Amazonia, and has been noted to contribute little to diminish social disparities in the region, despite some significant gains in terms of scale in the agricultural sector (Margullis, 2003). The State of Pará holds the second largest cattle herd in the Amazonian Region, second only to the State of Mato Grosso at a national level, with a herd of 16,856,561 heads of cattle in 2009. In 1990, the number of heads was $6,182,090$, indicating a significant growth of $173 \%$ in the past two decades.

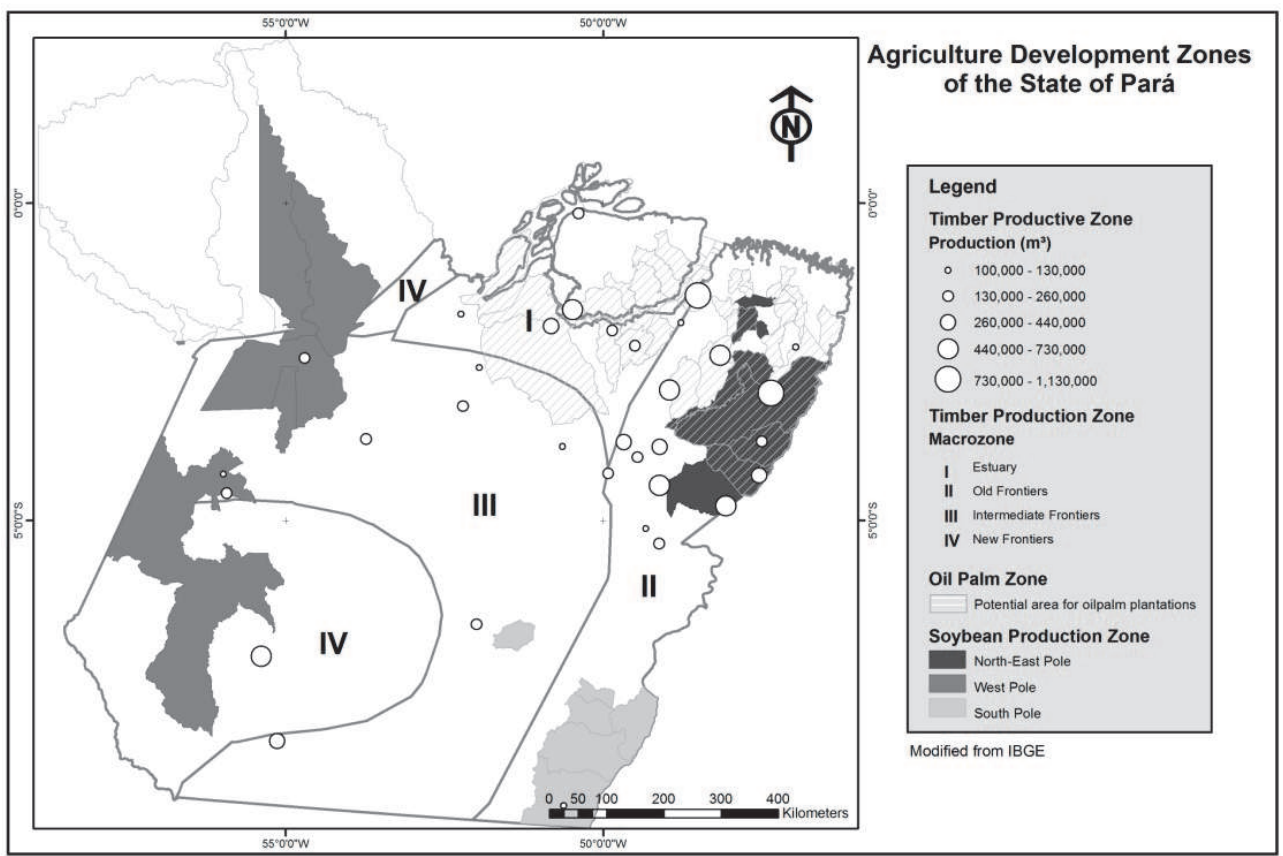

Fig. 3. Timber and agriculture development zones in the state of Pará, Brazil. 
The expansion of soybean plantations in the State of Pará was forwarded by the conversion of small family-owned ranches into aggregated agricultural lands, and by turning pasture into grain cultures. At the base of the land tenure structure, such an initiative has induced a new arrangement of productive territories, promoting the substitution of several small properties into a large sole-owned plantation (Guilhoto et al., 2006). Several reasons can be identified for the shift of a great number of rural entrepreneurs who took interest in expanding their activities from Mato Grosso into Pará: attractive international prices for soybean, good agricultural conditions and lower prices for land in the new State, and government incentive programs. With some previous experience and self-owned capital to cover crop costs and infrastructure investment, the newcomers the transformed land use patterns into a more intensive, technology-based productive areas.

This regional land use pattern led to the appearance of an array of export-driven facilities and infrastructure, helping the flow of soybean through the Amazon river. This is exemplified by the construction of the international Cargill grain port in the city of Santarem, with an investment of US\$20,000,000 and the capability to commercialize 800,000 tons of grains a year, with a storage capacity of 60,000 tons. In the same wave of investments, a new port near the State capital city of Belém is being constructed for the trading of soy, corn and sugar cane products. Following this trend, the conclusion of the dikes of the Tucuruí Dam, the second largest hydroelectric power plant dam in Brazil, leads one to expect this new port near Belém will become the largest fluvial export complex in the world, with an waterway extension of 2,5 thousand kilometers in the Tocantins-Araguaia river systems.

Concern for social problems in the wake of high deforestation rates induced by soybean plantations have caused a series of articulated campaigns by NGOs, the Catholic Church and rural workers syndicates, with serious accusations of violent land expropriation by locals at the service of large companies or individuals. Disparities in the process of land appropriation, involving different actors with a multitude of interests, are one of the main causes of social conflicts in Amazonia - a social paradox, if one considers the continental extension of the region and the extremely low index of demographic occupation. Public manifestations against the presence of soybean crops in Amazonia escalated into an international level, with the establishment of a 'moratorium on soy' originated in areas of tropical deforestation. In this particular case, international soy trade companies such as Cargill, Bunge, Dreyfuss and the Brazilian Maggi agreed in 2006 not to purchase and trade products coming from newly deforested areas in Amazonia. In 2008, the Brazilian Ministry of the Environment extended the moratorium until 2010, the Federal Government being responsible for coordinating the productive units, and putting NGOs in charge of monitoring compliance to the rules. Such environmental and social awareness led to the increase of certified crops in terms of sustainability and social benefits.

Palm oil has received special attention due to the edaphic and climatic adaptations of the plant in the northeastern portion of the State of Pará. Technical studies have shown that this particular oil is suitable as biofuel, and also as a substitute for trans fat in the food industry. Brazil has a potential of 232 million hectares of land for oil palm cultivation. The Amazonian Region is better adapted for such crops: the state of Pará answers for $80 \%$ of the production of the country, and is currently using 8,000 hectares of land, with a potential of 4-5 million hectares.

Brazil is also one of the main world producers of tropical timber. Processed wood production in 2009 reached 291 million $\mathrm{m}^{3}$, and Brazil contributed with 25 million $\mathrm{m}^{3}$, about $3 \%$ of the total amount exported worldwide, rounding up an income of 695 million dollars 
(3.5\%). The Brazilian share in the global market of plywood in 2009 was $4 \%$ of the total production. As plywood has a wide range of uses (construction, furniture, house utensils, etc.), its market value is higher and the exported volume claimed an income of US\$635 million.

Between 2000 and 2009, the Brazilian share of the total amount of sawed timber in the world remained around 11\%; there was nevertheless a sharp reduction in the past two years, with a decrease in 6 percent points in 2008 and 2009. This downward trend began in 2005, when the federal government started checking on illegal timber extraction, using a complex and efficient satellite system in Amazonia.

The distribution of international participation in tropical wood forest products reveals that Brazil still has an important role as a supplier of unprocessed material, while value aggregation in this economic chain occurs in developed countries of Europe, North America and Asia. Top-ranking importers of tropical sawn timber are the US, China, Japan, Italy and UK (Table 2). They consume altogether 40 million $\mathrm{m}^{3}$. A current decrease in the Brazilian production of timber is related to the growth rate of China.

\begin{tabular}{|c|c|c|c|c|c|}
\hline Country & Rank & $\begin{array}{c}\text { Imported } \\
\text { volume } \\
\text { (thousands } \\
\text { of } \mathrm{m}^{3} \text { ) }\end{array}$ & Country & Rank & $\begin{array}{c}\text { Import value } \\
\text { (thousands of US\$) }\end{array}$ \\
\hline US & 1 & $15,671.19$ & US & 1 & $3,236,649.27$ \\
China & 2 & $7,039.92$ & Japan & 2 & $2,360,697.14$ \\
Japan & 3 & $6,508.95$ & China & 3 & $1,891,849.20$ \\
Italy & 4 & $6,400.00$ & Italy & 4 & $1,876,209.22$ \\
UK & 5 & $5,070.00$ & UK & 5 & $1,714,667.89$ \\
\hline
\end{tabular}

Source: International Tropical Timber Organization (ITTO)

Table 2. Ranking of the main importers, in quantity and value, of sawn timber from tropical forests, 2009.

Expectations are of a growth in the market of tropical wood in the next coming years, with a simultaneous increase of pressure from environmental institutions demanding certified products and more efficient ground and remote sensing monitoring systems.

\section{REDD (Reducing Emissions from Deforestation and Forest Degradation): Solution or problem?}

In the center of the ongoing debate to assign value to forest conservation and green economy, a worldwide movement of carbon trade by reducing GHGs through the reduction 
of avoided forest deforestation and degradation has been discussed. However, there are concerns from some authors that this approach may not be fully applicable to avoid tropical deforestation -- specifically in the Brazilian Amazonia, where most of the natural tropical forests of the world are located.

The first point to be considered is the lack of data and reliable measurements, an issue that must be fully mastered before bringing this idea to a market economy (Kintisch, 2007). . The first problem with REDD is the lack of reliable data to provide information on tropical deforestation. An associated problem is the lack of capability in developing nations to provide accurate and verifiable measurements.

Since 1988, the Brazilian National Institute for Space Research (INPE) has conducted annual surveys of deforestation in the Brazilian Legal Amazonia, an area of about 5 million $\mathrm{km}^{2}$ which, until the 1950s, included 4 million $\mathrm{km}^{2}$ of tropical forests. INPE maps deforestation using LANDSAT-class images (30m resolution) and performs wall-to-wall measurements. The latest data produced by INPE used 330 images from the LANDSAT, CBERS and DMS systems, fully covering Amazonia. The results are detailed digital maps showing both the extent and the location of deforestation.

However, Brazil is currently the exception. There are no comparable maps being produced elsewhere. Thus, current estimates for other countries are based on unreliable methods, such as sampling, or on low-resolution satellite data, such as MODIS $250 \mathrm{~m}$ resolution images. The difference is substantial. For example, FAO estimates that $31,000 \mathrm{~km}^{2}$ of tropical forest was cut yearly in Brazil from 2000 to 2005, on average. By contrast, INPE's data gives an average of $21,500 \mathrm{~km}^{2}$ for the same period. Furthermore, the average for the entire Brazilian territory for the period $2005-2008$ is $14,300 \mathrm{~km}^{2}$, which is half of FAO's estimate.

Despite the problems with FAO's and other data sources, many researchers use such unreliable and outdated data as their source of information for assessing current global deforestation. IPCC AR4 estimated that deforestation accounts for between $10 \%$ and $20 \%$ of global GHG emissions. However, despite the proven unreliability of FAO's and other data, the uppermost value of the IPCC AR4 report (20\%) has been quoted widely in other governmental and multilateral reports and is being used in the current climate negotiations. For example, the recent G8 declaration in L'Aquila stated that "deforestation accounts for approximately $20 \%$ of annual CO2 emissions": no uncertainties, no error bars.

A major effort is needed to solve the problem of unreliable measures. First, data from remote sensing satellites needs to be available for all the world's tropical forests (Grainger, 2008). Based on INPE's experience, such data must at least be obtained from LANDSATclass satellites ( $30 \mathrm{~m}$ resolution, multispectral bands). The only continent for which such data are currently available is Latin America. Data are lacking for Africa, Southeast Asia, and Australasia. Data for India do exist but is not openly available. Furthermore, it will take at least three to five years before the data gap problem is solved.

Also, most tropical forest nations currently lack the skills to provide detailed and reliable estimates of land change. Moreover, to allow independent verification, data, methods, and maps must be made openly available on the Web. This poses a double problem for developing nations: capacity building and governance. How many governments would allow their national institutes to publish data that might be damaging to their own shortterm interests?

It could well take over a decade for a reliable system for monitoring tropical deforestation worldwide to be built. Building such as system would be a pre-requisite for REDD. This 
would demand a significant upfront investment from developed nations without any shortterm carbon credit benefits to them.

A second, and most important issue, is the correct definition of avoided deforestation. This concept is central to the REDD proposal. Yet this concept is misleading. Since there are many possible interpretations, one idea is to use the maximum acceptable level of deforestation for a tropical nation. Should the country reach a rate of deforestation lower than the cap (in a cap-and-trade scheme), it could trade the avoided emissions.

Take the case of Brazil. What is the maximum acceptable level of deforestation for Brazil? A direct attempt to answer this question could make use of historical rates. Given these rates, some proposals take a five-year moving average as the initial cap. This average is then reduced progressively as a target for the future deforestation.

There must be a concerted action by governments and markets for deforestation to slow down. The recent experience on Brazil shows what is possible. By a combination of market pressure and law enforcement, Brazil managed to reduce deforestation from $27,000 \mathrm{~km}^{2}$ in 2005 to $13,000 \mathrm{~km}^{2}$ in 2008. During the same period, the price of soybean increased from US $\$ 250$ per metric ton to US $\$ 500$ per metric ton. The price of beef oscillated from US $\$ 1.1$ per pound to US\$1.3 per pound. Thus, the decrease in deforestation is not correlated to commodity prices.

However, the rate of deforestation in Brazil remains high. The current five-year average should not be taken as a 'cap', below which Brazil would earn tradable carbon credits. The main reason is the stabilization of agricultural expansion and the current prevalence of cattle raising and timber extraction as the main drivers of deforestation. As a result, the economic value extracted from the land is much smaller than in the 1990s.

The three main areas of occupation in Amazonia are the States of Pará, Rondônia and Mato Grosso. In each State, there are different driving forces for deforestation (Aragao et al, 2008). A large part of the deforestation during the 1990s was associated with agricultural expansion. From 1990 to 2005, 110,000 km² were deforested in Mato Grosso, in the southern part of Amazonia. Such deforestation was associated to a large migration from farmers from the south of Brazil (States of Paraná, Santa Catarina and Rio Grande do Sul). This resulted in a large expansion of the soybean producing area and contributed to Brazil's exports. In 2008, Brazil produced 58 million tons of soybean; Mato Grosso accounted for 15 million tons ( $25 \%$ of total). The other states in Amazonia have no significant contribution to the production of grains.

Agricultural expansion has slowed down since 2000, due to four reasons: (a) a slowdown in migration from the South; (b) a relative stabilization of the production area, with emphasis on improved productivity; (c) newly available areas were found to have unfavorable soil conditions and worse connections to markets; and (d) the international market pressure for avoiding further deforestation. From 1970 to 1980, Mato Grosso's population almost doubled from roughly 600,000 to $1,130,000$ people. From 1980 to 1990, it increased to 2,000,000 people. Growth was smaller in the next decade, reaching 2,500,000 people in 2000. Less migrants means less pressure for new land. Furthermore, Greenpeace and ABIOVE (Brazilian Association for Vegetable Oil) have signed an agreement in 2006 (the "Soy Moratorium"), whereby the soybean exporters have pledged not to deforest any more land. The "Soy Moratorium" has been renewed in 2007 and 2008.

In short, the current levels of deforestation in Amazonia are too high and too unsustainable to be considered as a maximum acceptable level below which Brazil could get tradable carbon 
credits. Therefore, Brazil would need to achieve significant gains in fighting deforestation before it could reach an annual rate that could be considered 'acceptable'.

Other problems central to this issue, concerning the final destination of the money resulting from carbon credits to be negotiated from the REDD system, and the potential problem of distorting markets, also have to be addressed in detail. Considering that large-scale deforestation are associated with expected economic returns, market forces could provide an effective alternative to REDD.

\section{Global markets, local challenges}

A renewed vision of nature as a source of well-being, and how such a limited resource can affect humans lives, has given the Amazon forest an strategic value in the new frontier of natural capital (United Nations Environment Programme-UNEP, 2010), bringing the region to the center stage of distinct and diverse interests, as well as of conflicting demands. This view needs to be dealt with for the better and efficient use of the Amazonian natural heritage to the benefit of local and global societies. In an apparent paradox, international interests in the use of the Amazonian natural capital is in conflict with the predominant Brazilian national view of a mobilization in order to oversee Amazonia as a vast space for sustainable businesses, which would strengthen regional development-related actions.

The predominant environmental policy since the 1980s to the beginning of the third millennium has given signs of trouble in fully confronting the new globalization agenda. Its major, most evident result was the demarcation of record-size tropical land territories for preservation and/or sustainable, and as protected lands for indigenous territories and biological conservation units, corresponding to $20 \%$ of the regional Amazonian territory in Brazil. However, there is a common agreement that protected areas are not sufficient to refrain further deforestation or to induce economic growth under a globalized world perspective. Protection actions have not been able to contain the expansion of newly productive lands to respond for global demands for food and energy, as well as to meet the growing demand of local communities in the region. Therefore a new standard of regional development is needed.

At a global level, conflicts of interest in the use of natural assets of Amazonia can be associated to three different market categories:

The market of proteins represented by soybean and beef, dominated by big agribusiness industries and owners of extensive ranchland. The growing international demand stimulates the exporting of soybean and cattle, which encompasses huge extensions of cerrado in the soy-beef belt that extends from Bolivia to the States of Bahia and Piauí in Brazil. Such a pressure reinvigorates the mobility and expansion of that economic land belt into forested areas, enhancing land tenure conflicts in the southern fringes of the Amazonian Biome. In this case, two types of land use and predominant action upon territories are put into conflict, with technological and logistic disparities between them: the large companies and land owners against local and traditional communities. Despite the high mobilization and volume in economic transactions, agribusiness in the long run does not seem as either a sustainable or a social solution for the entire region. In the future, this market should be confined to the exploration of areas of cerrado and currently deforested regions, without further destruction of the remaining primary and old secondary forests.

The market of natural goods, characterized by the financial interests of large multinational banks, such as BIRD and BID, which strive to organize it. It is the case of the Clean Air 
market, which is the more advanced in the discussions of the Kyoto Protocol, and the mechanism of clean development. More recently the REDD mechanism brought into play the Market of Life, with the intention to organize everlasting meetings under the Biodiversity Convention protocol. A third case is the Market of Water, which, under global regulation, is being taken by different multilateral agencies as well.

A third important market component is represented by the problems facing environmental issues related to oil production and energy, with the intensification of conventional ways of production - hydroelectric power, oil and gas - as well as of the bioenergy paradigm that expands greatly in the Brazilian territory, including the eastern Amazonian Region.

In a more regional view, there are growing demands for better social and economic conditions of the 20 million inhabitants of Amazonia. Intense transformations have occurred in the societies locally in the past decades, transforming the region with a coherent internal consistency expressed by social demands and aspirations. State-level governments, international cooperation and, especially, organized civil societies have transformed the region and gave it a heavier weight in the political arena. Demands for better living conditions and development requirements cannot be ignored in regional and national development projects.

At a national level, this conflict of interests seems to immobilize the Federal Government, which proves unable to define a consistent, long-term regional agenda for Amazonia. The main task is to confront globalized demands of prosperity and, at the same time, try to solve crucial social problems. Despite recent public policies that tried to stop deforestation through costly command and control programs, sustainable development was not simultaneously encouraged, and in practice there were few effective results.

It is also important to notice the mismatch between the magnitude of the potential of resources with the restricted number of entrepreneurs, which translates in low levels of regional production. In other words, business opportunities are waiting for bold and competent businessmen to fulfill the potential for prosperity in the region. Among the various protein and the natural goods markets, great opportunities exist in the valuation of forest ecosystems. Such unexploited assets hold the most strategic potential in the millennium for a sustainable exploitation of biodiversity, water, tourism, etc.

The bioenergy trend opens clear opportunities for countries to optimize their energy matrix, where Brazil, due to its geographical extension and tropical situation, has the potential to become one of the largest exporters of energy in the world.

\section{Conclusions}

The Amazonian Region can contribute to the dynamic trends of use and management of resources in the tropical world. The great challenge, however, is to produce social justice and economic profits to be shared with most of the population without destroying further natural ecosystems.

In this case some challenges should be put up front in order to promote the development of the region. One prerequisite is to make economic growth compatible with social inclusion, minimizing the destruction of natural habitats. We can suggest three strategic actions in this regard:

1. To invest in science, technology and innovation. The destruction of the forest will only be halted if there is some economic value that may compete with agribusiness, unsustainable timber exploitation and cattle ranching; 
2. To have a customized, long-term regional development policy program as a prerequisite for Governmental strategy, to reduce intraregional disparities and adjust development agendas coined with potentials and challenges of each region;

3. To strengthen institutional agendas, decoding regional society demands into Government actions. It is in this segment where the institutional strategy of governance and accountability for development and economic actions will be established;

On the other hand, while environmental conservation and economic development are often thought to be at odds, Brazil's approach strives to merge the two in Amazonia. The rise of new commodities in Brazilian Amazonia is particularly relevant for understanding Brazil's current economic success, with growth at a record 9\% in the first quarter of 2010. Although Legal Amazonia contributes with less than $10 \%$ of the national GDP, new industries and emerging markets involving payments for ecosystem services hold the potential to sway billions of dollars of wealth to the nation because of Amazonian resources. These important attributes are tempered by social unrest and often extreme inequalities in the region, which keep a significant portion of the population living with high rates of agrarian conflict and rural poverty. It is fair to hope that today's "green commodities boom" in Amazonia will not be destined to repeat the same unfortunate conjunctures of environmental losses and social conflicts that have tarnished the history of the region.

We defend that, to better organize the economic trends demanding more productive land, sustainability programs on managed territories (see sustainable territory sensu Vieira et al, 2005) may be important so as to minimize impacts and to optimize actions on conservation. The scientific framework of a sustainable territory, based on a multidisciplinary program with transdisciplinary actions, is a solid approach for combining conservation and economic production in rural areas of Amazonia. Its basic premise is that the combination of scientific information and the best practices of land use and conservation can yield customized solutions for rural production areas. The scope and scale of activities, as well as the economic features of the farmers, are diverse and change through time. Despite such features, recent studies have established which activities might yield better ecological services and help enhancing the quality of life in rural populations. Therefore, linking scientists with public interests is an important part of the equation of sustainability in the Amazonian Region.

\section{References}

Aragao, L.; Malhi, Y.; Barbier, N.; Lima, A.; Shimabukuro, Y.; Anderson, L.; Saatchi, S. (2008) Interactions between rainfall, deforestation and fires during recent years in the Brazilian Amazonia. Philosophical Transactions, vol. 363, 1779-1785. ISSN 09628436

Araújo, R. \& Lená, P. (2010). Da Predação à Sustentabilidade na Amazônia: A Difícil Metamorfose. In: Desenvolvimento Sustentável e Sociedades na Amazônia, R. Araújo \& P. Lená, (Eds.), 13-53, Editora Museu Goeldi, ISBN 978-85-61377-46-5 , Belém-Pará, Brazil.

Buckeridge, M.S. (2008). Biologia e Mudanças Climáticas no Brasil. Editora RIMA, São Carlos, Brasil. 295 p. ISBN 9788576561439 
Burnham, R.J \& Johnson, K.R. (2004). South American palaeobotany and the origins of neotropical rainforests. Philosophical Transactions of Royal Society of London. B vol. 359 no. 1450 1595-1610 ISSN 1471-2970

Bush, M.B.; Silman, M.R. 2007. Amazonian exploitation revisited: ecological asymmetry and the policy pendulum Front Ecol Environ 5(9): 457-465.ISSN 1540-9295

Diaz, S.; Hector, A. \& Wardle, D.A. (2009) Biodiversity in forest carbon sequestration initiavies: not just a side benefit. Current Opinion in Environmental Sustainability, No.1, pp. 55-60, ISSN 1877-3435

Dirzo, R..\& Raven, P. (2003). Global state of biodiversity and loss. Annual Review of Environment and Resources. Vol. 28, pp. 137-167. ISSN 1441-9335

Dirzo, R.; Aguirre, A. \& López, J.C. (2008). Diversidad florística de las selvas húmedas en paisajes antropizados. Investigación Ambiental. No. 1, pp. 17-22

Grainger, A. (2008) Difficulties in tracking the long-term global trend in tropical forest area. Proceedings of the National Academy of Sciences, Vol. 105 pp 818. ISSN 0027-8424

Green, R. E.; Cornell,S.J.; Scharlemann, J.P. \& Balmford, A. (2005). Farming and the fate of wild nature. Science Vol.307. Pp. 550-555. ISSN 1095-9203

Gallagher, K.P. and R. Porzecanski. (2010). The Dragon in the Room: China and the Future of Latin American Industrialization. Stanford University Press, California. ISBN 9780804775-98-4

Guilhoto J. J. M.; Silveira, F. G.; Ichiara, S. M.; Azzoni, C. R. (2006) A importância do agronegócio familiar no Brasil. Revista de Economia e Sociologia Rural, Vol 44, No. 3 , pp. 355-383, ISSN 0103-2003

Instituto Brasileiro de Geografia e Estatística- IBGE (2006). Censo Agropecuário.

Available from www.ibge.gov.br

Instituto nacional de Pesquisas Espaciais - INPE (2010). PRODES. Available from www.inpe.br

Instituto de Pesquisas Econômicas Aplicadas - IPEA (2011). Sustentabilidade Ambiental no Brasil: biodiversidade, economia e bem-estar humano. Comunicados do IPEA, No.78, Série Eixos do Desenvolvimento Brasileiro.

Available from www.ipea.gov.br

ITTO. International Tropical Timber Organization (ITTO). Available from: www.itto.int

Joels, L. C. \& Câmara, G. (2001) Modelos e cenários para a Amazônia: o papel da ciência. Parcerias Estratégicas, Vol. 12, pp. 129-134. ISSN 1413-9375

Kintisch, E. (2007). Carbon Emissions: Improved Monitoring of Rainforests Helps Pierce Haze of Deforestation. Science, Vol. 316, pp.536-537. ISSN 1095-9203

Laurance, W.F.; Albernaz, A.K.M; Schroth, G.; Fearnside, P.M.; Bergen, S.; Venticinque, E.M. \& da Costa, C. ( 2002). Predictors of deforestation in the Brazilian Amazon.. Journal of Biogeography. Vol.29, pp. 1365-2699. ISSN: 0305-0270

Margullis, S. (2003). Causas do desmatamento na Amazonia Brasileira. ISBN: 85-88192-10-1 Avaiable from www.bancomundial.org.br

Martinelli, L. A.; Naylor, R.; Vitousek, P. M. \& Moutinho, P. (2010). Agriculture in Brasil: impacts, costs, and opportunities for a sustainable future. Current Opinion in Environmental Sustainability. Vol. 2, pp. 1-8. ISSN 1877-3435 
Mittemeir, R.A; Fonseca, G. A.B. da; Rylands, A.B. \& Brandon, K. (2005). A Brief History of Biodiversity Conservation in Brazil. Conservation Biology, Vol. 19, No. 3, (June 2005), pp. 601-607. 2010 ISSN ISSN 0888-8892

Mooney, H.; Larigauderie, A.; Cesario, M.; Elmquist, T.; Hoegh-Guldberg, O.; Lavorel, S.; Mace, M. G.; Palmer, M.; Scholes, R. \& Yahara, T. (2009). Biodiversity, climate change, and ecosystem services. Current opinion in Environmental Sustainability, No. 1, pp.46-54, ISSN 1877-3435

Moran, E.F. \& Ostrom, E. (2009. Ecossistemas florestais. Interação Homem-Ambiente. EDUSP editora, São Paulo. 543 p. ISBN 9788531411342

Pereira, H. M.; Leadley, P.W.; Proença, V.; Alkemade, R.; Scharlemann, J. P.W.; FernandezManjarrés, J.F.; Araujo, M.B.; balvanera, P.; Biggs, R.; Cheung. W.W.L.; Chini, L.; Cooper, H.D.; Mace, G.M.; Oberdorff, T.; Revenga, C.; Rodrigues, P.; Scholes, R.J.; Sumaila, U. R. \& Walpole, M. (2010). Scenarios for Global Biodiversity in the 21st Century. Science, Vol. 330, pp.1095-9203, ISSN 1095-9203

Peres, C.A.; Barlow, J. \& Laurance, W. (2006). Detecting anthropogenic disturbance in tropical forests. Trends in Ecology and Evolution. Vol. 21, pp. 227-229. ISSN: 01695347

Peres, C.A.; Gardner, T.A.; Barlow, J.; Jansen, J.; Michalski, F.; Lees, A.C.; Vieira, I.C.G.; Moreira, F.M.D.; \& Feeley, K.. (2010). Biodiversity conservation in humanmodified Amazonian forest landscapes. Biological Conservation, pp. 2314-2327, ISSN 0006-3207

Silva, J. M. C.; Rylands, A. B. ; Fonseca, GAB. (2005) The fate of the Amazonian areas of endemism. Conservation Biology, Vol. 19, No. 3, pp. 689-694. ISSN 0888-8892

Scharlemann, J.P.W. \& Laurance, W.F. (2008) How green are biofuels? Science Vol, 319, pp. 43-44, ISSN 1095-9203

Smeraldi, R. and P. May. 2008. O Reino do Gado: Uma Nova Fase na Pecuarização da Amazônia Brasileira. Amigos da Terra, Brasília.

Avaiable from www.amigosdaterra.org.br

Sparovek, G. 2009. Environmental, land-use and economic implications of Brazilian sugarcane expansion 1996-2006 Mitigation and Adaptation Strategies for Global Change, 14: 285-298 ISSN 1381-2386

Stuart, N.S.; E.O. Wilson; J.A.McNelly; R.A. Mittermeier; and J.P. Rodriguez. (2010). The barometer of life. Science, Vol.328, p.177, ISSN 1095-9203

Stuart, H.; Butchart, M.; Walpole, M.; Collen, B.; van Strien, A.; Scharlemann, J. P.W.; Almond, R. E. A.; Baillie, J.E.M.; Bombard, B.; Brown, C.; Bruno, J.; Carpenter, K.E.; Carr, G.M.; Chanson, J.; Chenery, A.M.; Csirke J.; Davidson, N.C.; Dentener, F.; Foster, M.; Galli, A.; Galloway, J.N.; Genovesi, P.; Gregory, R.D.; Hockings, M.; Kapos, V.; Lamarque, J-F.; Leverington, F.; Loh, J.; McGeoch, M.A.; McRae, L.; Minasyan, A.; Morcillo, M. H.; Oldfield, T. E.E.; Pauly, D.; Quader, S.; Revenga, C.; Sauer, J.R.; Skolnik, B.; Spear, D.; Stanwell-Smith, D.; Stuart, S.N.; Symes, A.; Tierney, M.; Tyrrell, T.D.;Vié, J-C. \& Watson, R. (2010). Global

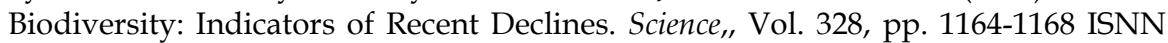
1095-9203

Tallis, H. \& Kareiva, P. (2005). Ecosystem services. Current Biology. Vol.15, PP. R746-758. ISSN: 0960-9822 
Vieira, I.C.G.; Silva, J.M.C. da; Toledo, P. M. (2005). Estratégias para Evitar a Perda de Biodiversidade na Amazônia. Estudos Avançados, USP, Vol. 19, No.54, pp. 153-164. ISSN 0103-4014 UNEP. (2010). TEEB report. Avaiable from www.unep.org

Vieira, I.C.G.; Toledo, P. M; Silva, J.M.C. da \& Higuchi , H.. (2008) Deforestamention and Threats to the Biodiversity of Amazonia. Brazilian Journal of Biology Vol., 68, pp. 631637. ISSN 1519-6984 


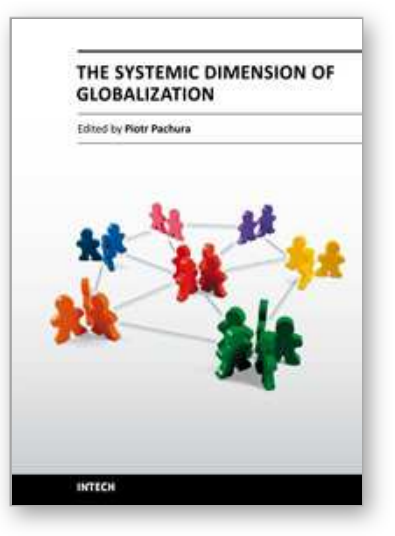

\author{
The Systemic Dimension of Globalization \\ Edited by Prof. Piotr Pachura
}

ISBN 978-953-307-384-2

Hard cover, 288 pages

Publisher InTech

Published online 01, August, 2011

Published in print edition August, 2011

Today science is moving in the direction of synthesis of the achievements of various academic disciplines. The idea to prepare and present to the international academic milieu, a multidimensional approach to globalization phenomenon is an ambitious undertaking. The book The Systemic Dimension of Globalization consists of 14 chapters divided into three sections: Globalization and Complex Systems; Globalization and Social Systems; Globalization and Natural Systems. The Authors of respective chapters represent a great diversity of disciplines and methodological approaches as well as a variety of academic culture. This is the value of this book and this merit will be appreciated by a global community of scholars.

\title{
How to reference
}

In order to correctly reference this scholarly work, feel free to copy and paste the following:

Peter Mann de Toledo, Ima Célia Guimarães Vieira, Gilberto Câmara, Roberto Araújo, Andrea Coelho and Sergio Gomes (2011). Biodiversity, Ecosystem and Commodities in Amazonia, The Systemic Dimension of Globalization, Prof. Piotr Pachura (Ed.), ISBN: 978-953-307-384-2, InTech, Available from: http://www.intechopen.com/books/the-systemic-dimension-of-globalization/biodiversity-ecosystem-andcommodities-in-amazonia

\section{INTECH}

open science | open minds

\author{
InTech Europe \\ University Campus STeP Ri \\ Slavka Krautzeka 83/A \\ 51000 Rijeka, Croatia \\ Phone: +385 (51) 770447 \\ Fax: +385 (51) 686166 \\ www.intechopen.com
}

\author{
InTech China \\ Unit 405, Office Block, Hotel Equatorial Shanghai \\ No.65, Yan An Road (West), Shanghai, 200040, China \\ 中国上海市延安西路65号上海国际贵都大饭店办公楼405单元 \\ Phone: +86-21-62489820 \\ Fax: +86-21-62489821
}


(C) 2011 The Author(s). Licensee IntechOpen. This chapter is distributed under the terms of the Creative Commons Attribution-NonCommercialShareAlike-3.0 License, which permits use, distribution and reproduction for non-commercial purposes, provided the original is properly cited and derivative works building on this content are distributed under the same license. 